\title{
The influence of corruption and governance in the delivery of frontline health care services in the public sector: a scoping review of current and future prospects in low and middle-income countries of south and south-east Asia
}

Nahitun Naher ${ }^{1 *}$, Roksana Hoque ${ }^{1}$, Muhammad Shaikh Hassan¹, Dina Balabanova², Alayne M. Adams ${ }^{3}$ and Syed Masud Ahmed ${ }^{1}$ (D)

\begin{abstract}
Background: The dynamic intersection of a pluralistic health system, large informal sector, and poor regulatory environment have provided conditions favourable for 'corruption' in the LMICS of south and south-east Asia region. 'Corruption' works to undermine the UHC goals of achieving equity, quality, and responsiveness including financial protection, especially while delivering frontline health care services. This scoping review examines current situation regarding health sector corruption at frontlines of service delivery in this region, related policy perspectives, and alternative strategies currently being tested to address this pervasive phenomenon.

Methods: A scoping review following the Preferred Reporting Items for Systematic Reviews and Meta-Analysis (PRISMA) was conducted, using three search engines i.e., PubMed, SCOPUS and Google Scholar. A total of 15 articles and documents on corruption and 18 on governance were selected for analysis. A PRISMA extension for Scoping Reviews (PRISMA-SCR) checklist was filled-in to complete this report. Data were extracted using a pre-designed template and analysed by 'mixed studies review' method.

Results: Common types of corruption like informal payments, bribery and absenteeism identified in the review have largely financial factors as the underlying cause. Poor salary and benefits, poor incentives and motivation, and poor governance have a damaging impact on health outcomes and the quality of health care services. These result in high out-of-pocket expenditure, erosion of trust in the system, and reduced service utilization. Implementing regulations remain constrained not only due to lack of institutional capacity but also political commitment. Lack of good governance encourage frontline health care providers to bend the rules of law and make centrally designed (Continued on next page)
\end{abstract}

\footnotetext{
* Correspondence: nahitun.naher@bracu.ac.bd

'BRAC James P. Grant BRAC School of Public Health, BRAC University, 5th

Floor(Level-6), icddrb Building, 68 ShahidTajuddin Ahmed Sarani, Mohakhali,

Dhaka 1212, Bangladesh

Full list of author information is available at the end of the article
}

(c) The Author(s). 2020 Open Access This article is licensed under a Creative Commons Attribution 4.0 International License, which permits use, sharing, adaptation, distribution and reproduction in any medium or format, as long as you give appropriate credit to the original author(s) and the source, provide a link to the Creative Commons licence, and indicate if changes were made. The images or other third party material in this article are included in the article's Creative Commons licence, unless indicated otherwise in a credit line to the material. If material is not included in the article's Creative Commons licence and your intended use is not permitted by statutory regulation or exceeds the permitted use, you will need to obtain permission directly from the copyright holder. To view a copy of this licence, visit http://creativecommons.org/licenses/by/4.0/ The Creative Commons Public Domain Dedication waiver (http://creativecommons.org/publicdomain/zero/1.0/) applies to the data made available in this article, unless otherwise stated in a credit line to the data. 


\begin{abstract}
(Continued from previous page)
anti-corruption measures largely in-effective. Alternatively, a few bottom-up community-engaged interventions have been tested showing promising results. The challenge is to scale up the successful ones for measurable impact.

Conclusions: Corruption and lack of good governance in these countries undermine the delivery of quality essential health care services in an equitable manner, make it costly for the poor and disadvantaged, and results in poor health outcomes. Traditional measures to combat corruption have largely been ineffective, necessitating the need for innovative thinking if UHC is to be achieved by 2030.
\end{abstract}

Keywords: Health-sector corruption, Good governance, Frontline health care services, Frontline health care providers, UHC, LMICS

\section{Background}

The goal of Universal Health Coverage (UHC) is that everyone needing health care can access quality services without financial hardship, and attains sustainable health outcomes [1]. To facilitate the journey towards UHC in low- and middle income- countries (LMICs), improving Primary Health Care (PHC) through health systems strengthening is essential [2]. However, 'corruption' contributes to undermine the UHC goals of equity, quality, and responsiveness of health systems and ultimately results in high, sometimes catastrophic, health care expenditures $[3,4]$. Corruption, the 'use, misuse or abuse' of public office or resources for private gain $[5,6]$ may be actual or potential, financial, or even political [7]. It represents an abuse of trust and intentional violation of duty [8], and results in negative impacts on population health outcomes especially for the poor and the disadvantaged. For example, corruption (according to Transparency International's corruption perception index) is estimated to be responsible for 140,000 annual deaths globally among under five children [9]. Higher levels of corruption (according to the same index) has been found to be associated with self-reported poor general health of both men and women, within all socio-economic groups across the lifecycle, in 20 African countries [10]. Also, corruption has beenincriminated as a cause in deaths from road traffic accident crashes, and deemed to be a necessary condition for effectively tackling road safety problems [11].

Corruption is a usual consequence of poor governance characterized by lack of transparency, weak accountability and inefficiency, and lack of citizen participation [12]. The importance of governance on the delivery of effective health care services cannot be overemphasized, even in situations where greater investments in the public health sector are occurring in tandem with economic growth [3]. 'Good governance' facilitates better allocation and efficient use of available resources including better and effective targeting of priority population groups for intervention [13, 14]. In a recent study based on national level panel data for $\sim 148$ countries, quality of government has been found to directly impact upon the infant and under-five child mortality, maternal mortality, and life expectancy [15]. The authors found that reducing corruption, one of the tenets of quality government, can significantly reduce infant and under-five child mortality.

The issue of corruption in the health sector is pervasive [16]. The particular susceptibility of the health sector to corruption arises from the asymmetry of information that characterizes the patient-provider relationship, the uncertainty that surrounds the illness experience, the multiplicity of actors and services involved in illness care, and the challenges of ensuring accountability in complex health systems [17]. Expensive hospital construction, high tech equipment and the increasing arsenal of medicines needed for treatment, combined with a powerful market of vendors and pharmaceutical companies present opportunities for corruption in the health sector. These opportunities increase when there is insufficient accountability for decisions or results in organisations. Organisational culture can further legitimize this behaviour by influencing individual attitudes and norms towards corruption and making it socially acceptable [18].

There is a rising trend of corruption in LMICs in the south and south-east Asian regions [19]. In these countries, the intersection between a pluralistic health system, a largely informal health market, and a poor regulatory regime have provided conditions favourable for corruption [20]. Besides, resource constraints in public sector resulting in poor salaries for the health care providers and inadequate supplies increase corruption such as informal payment and bribes [21, 22]. The conventional top-down approach of reward and punishment based on strict implementation of rules and regulations combined with various incentives to curb corruption ('carrot and stick' measure), has largely been unsuccessful in these countries [23]. This is partly due to the fact that health sector corruption is most often manifested at the level of patient encounter where providers (as 'street-level bureaucrats') have the freedom to shape the type and quality of care provided in the privacy of the doctor's office [24]. 
Given the fact that traditional top-down approach of combating corruption through regulatory mechanisms and incentives have largely failed in LMICs, alternative, innovative approaches are needed that make the 'cost of corruption' outweigh its benefits [23, 25]. To identify bottom-up strategies that are perceived as 'win-win' for the stakeholders involved, an understanding of what is happening and why at the forefront of health care service delivery is necessary. Focusing on LMICs in the south/south-east Asian region, this scoping review documents and critically assesses relevant evidence on health sector corruption at the frontlines with the purpose of filling-in this knowledge gap. Study findings are expected to help policy makers and practitioners design innovative interventions that go beyond the traditional approaches to contain corruption.

\section{Methods}

A scoping review following the Preferred Reporting Items for Systematic Reviews and Meta-Analysis (PRISMA) was conducted, using three search engines i.e., PubMed, SCOPUS and Google Scholar. A protocol was developed to guide the literature review process which specified study objectives, key research questions, inclusion/exclusion criteria, data sources (Table 1), and key search terms (Table 2). A PRISMA extension for Scoping Reviews (PRISMA-ScR) checklist was filled-in to complete this report (Additional File 1). Data were extracted using a pre-designed template and analysed by the 'mixed studies review' method [26].

\section{Search strategy}

We searched information from published articles and documents as shown in the PRISMA flow diagram (Fig. 1). The search strategy and terms were developed collaboratively with our study partners. Search strategy focused on following key words: corruption, informal payment, rent-seeking behaviors, bribery, anticorruption strategy and/or behavior, governance/ good governance and/or accountability in frontline health workers/managers, service providers of health facilities/ system, hospitals, etc. The literature search was conducted during Sept. - Oct. 2017 and the full search strategy is available on request from the authors. Citations for journal articles were managed using EndNote X7.7.1 software.

\section{Operational definitions}

For our purpose, the key concepts of the study are defined as follows (10): i) Corruption: the abuse of

Table 1 Literature review protocol

\begin{tabular}{|c|c|c|}
\hline \multirow[t]{3}{*}{ Objectives } & \multicolumn{2}{|c|}{$\begin{array}{l}\text { To understand current scenario and policy perspective in selected countries of the south and south-east Asia region to address ir- } \\
\text { regularities and informal practices in the public sector frontline }(\mathrm{PHC}) \text { health care facilities }\end{array}$} \\
\hline & \multicolumn{2}{|c|}{$\begin{array}{l}\text { To identify different types of irregularities and informal practices perpetrated by the frontline health care service provider in countries } \\
\text { of south and south-east Asia }\end{array}$} \\
\hline & \multicolumn{2}{|c|}{ To explore different innovative approaches practiced in this region to address irregularities and informal practices. } \\
\hline \multirow[t]{5}{*}{$\begin{array}{l}\text { Research } \\
\text { Questions }\end{array}$} & \multicolumn{2}{|c|}{$\begin{array}{l}\text { What are the different types of irregular and informal } p \\
\text { public sector? }\end{array}$} \\
\hline & \multicolumn{2}{|c|}{ What motivates them to engage in corrupt practices? } \\
\hline & \multicolumn{2}{|c|}{ What are the conditions that incentivize corrupt behavior among them? } \\
\hline & \multicolumn{2}{|c|}{ Which anti-corruption initiatives promote transparency and accountability among public sector health care providers? } \\
\hline & \multicolumn{2}{|c|}{ How does the legal and regulatory framework promote or constrain corrupt practices by these providers? } \\
\hline \multirow{6}{*}{$\begin{array}{l}\text { Search } \\
\text { Strategy }\end{array}$} & \multirow[t]{3}{*}{ Inclusion Criteria } & Peer-reviewed, full-text articles, all methods, all design, written in English \\
\hline & & Policy data involved with health sector corruption and governance from central to community \\
\hline & & Grey materials (published and/or unpublished) \\
\hline & Exclusion criteria & Corruption related literature not with a reference or focus on health sector \\
\hline & Time frame & January 2007 to August 2017 \\
\hline & $\begin{array}{l}\text { Selected south and south- } \\
\text { east Asian LMICs }\end{array}$ & Bangladesh, Bhutan, India, Indonesia, Nepal, Sri Lanka, Myanmar, Vietnam, Philippines \\
\hline \multirow[t]{4}{*}{ Data source } & Electronic database & PubMed, SCOPUS and Google Scholar \\
\hline & Grey literature & $\begin{array}{l}\text { National Bangla \& English newspaper articles; Health related blog in English and Bangla; Books/ } \\
\text { Monograph/ dissertation/ conference paper/conference proceedings }\end{array}$ \\
\hline & Organizational website & $\begin{array}{l}\text { The World Bank, Anti-corruption Resource Centre, Transparency International Bangladesh, Center for } \\
\text { Global Development, CHR Michelson Institute, WHO, Ministry of Health \& Family Welfare (MoHFW), } \\
\text { Director General of Health Services (DGHS), Director General of Family Planning (DGFP), }\end{array}$ \\
\hline & website & th Policy and Planning etc. \\
\hline
\end{tabular}


Table 2 Key terms used for searching electronic databases

\begin{tabular}{llll}
\hline $\begin{array}{l}\text { Corruption (combined by 'OR') } \\
\text { (a) }\end{array}$ & $\begin{array}{l}\text { Governance/accountability (combined by } \\
\text { 'OR') (b) }\end{array}$ & $\begin{array}{l}\text { Health sector (combined by } \\
\text { 'OR') (c) }\end{array}$ & $\begin{array}{l}\text { Geographic location (combined by } \\
\text { 'OR') (d) }\end{array}$ \\
\hline Corrupt & Governance & Hospital & Bangladesh \\
Bribery & Good governance & Health care center & Bhutan \\
Dishonesty & Accountability & Health facilities & India \\
Anti-corrupt & Community accountability & Health service & Indonesia \\
Tackle corrupt & & Health worker & Myanmar \\
Combat corrupt Anti-corrupt & & Frontline health care provider & Nepal \\
strategy & & Sri Lanka \\
Rent seeking behavior & & Manager & Philippines \\
Informal payment & Administrator & Vietnam \\
Informal practice & Service provider & LMICs \\
Illegal practice & & LICs \\
Elicit practice & & \\
Speed up money & & \\
\hline
\end{tabular}

Note: $a, b, c, d$ groups were combined with Boolean operator 'AND'

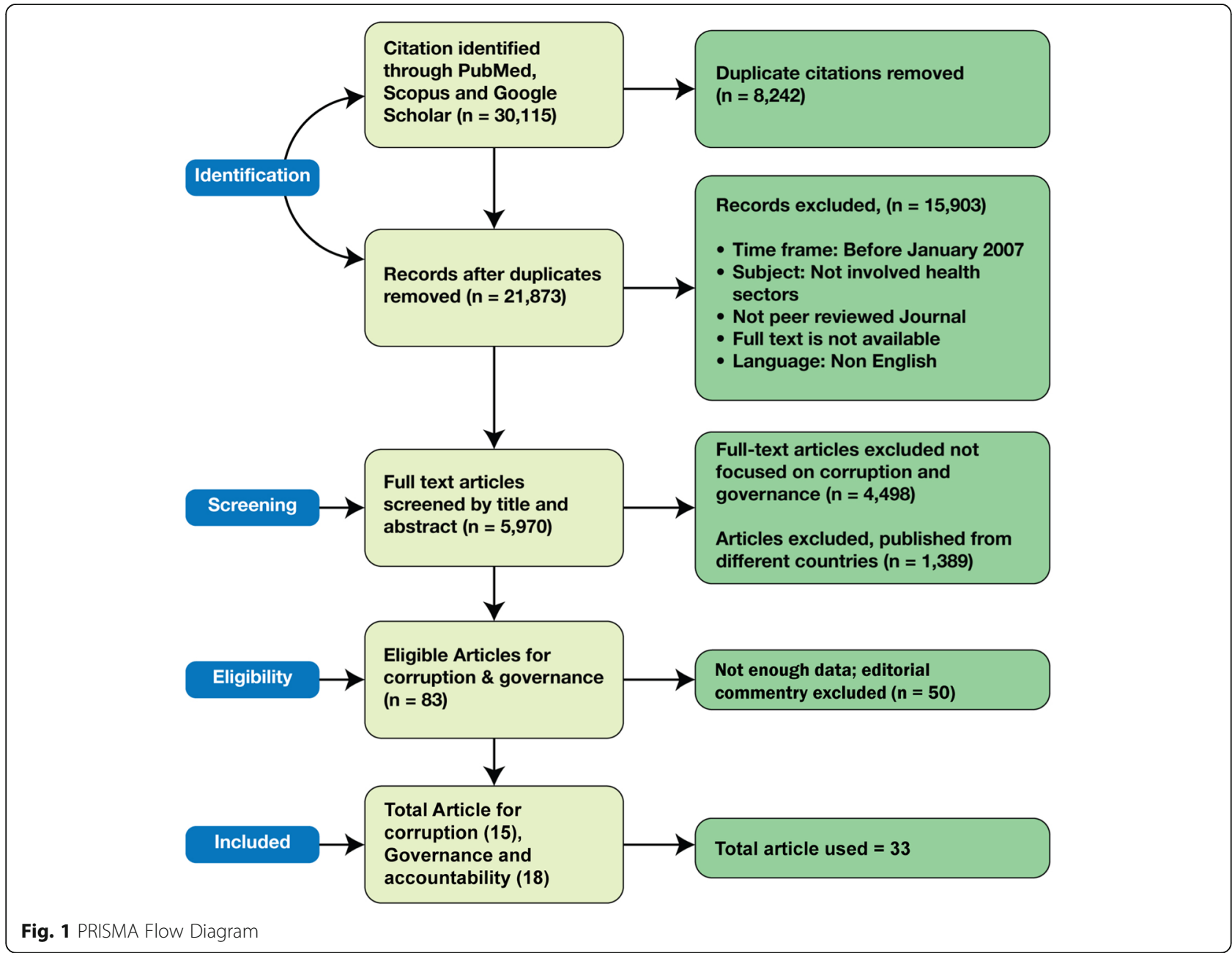

Fig. 1 PRISMA Flow Diagram 
entrusted power for private gain (actual or potential, to be realized in the future), alternatively described as "irregularities and informal practices and/or rent-seeking;" also encompasses concepts of transparency (honesty and openness) and accountability ('the extent to which people, groups and institutions are able to hold government and other power holders responsible for their actions'), the two pillars of 'good governance'; ii) Informal payment: payments made to health providers for services supposed to be provided free of charge or payments made that are greater than official fees; (alternative terms used: 'under the counter/table payment,' 'envelop payment,' 'unofficial fees' etc.), payments made outside official channels, payments over and above fixed copayments, and additional payments for entitled services [27] iii) Bribes: cash or kind exchanged with the health service providers/officials against an official action (e.g., posting and transfer to health facilities of choice); iv) Absenteeism: stealing time by not coming to work or doing private practice during working hours [28]; v) Frontline health care services and frontline health care workers: Essential health care services delivered by the doctors, nurses, paramedics, CHWs and lab and pharmacy technicians at the public sector sub-district (upazila) health facilities and below (the formal level of PHC); vi) Regulatory regime: arrangements of steering and control mechanisms that influence the operation of health systems e.g., statutory measures for controlling the practice of medical profession or health facilities, or marketing of medicines and medical devices etc. vii) Decentralisation: a socio-political process that transfers authority and responsibility in planning, management and decision-making from central government to local government bodies.

\section{Data extraction and synthesis}

Two researchers from the study team identified the articles independently from electronic databases, grey literature, and manual search. After excluding duplications, screening titles and abstracts, and applying eligibility criteria, a total of 36 articles and documents were included for data extraction and analysis (Fig. 1). A pre-designed template was used for extraction of data from the selected articles and documents. The two key themes of the study viz. corruption and governance, were subsequently disaggregated into sub-themes for further granularity: corruption (types and forms, practices, opportunities and incentives, impact) and governance (transparency, accountability, laws and regulations, citizen engagement) (Table 3). We used a 'mixed studies review' method to synthesize evidence from quantitative, qualitative and mixed methods studies, which is particularly effective when analyzing complex public health interventions [26]. Any confusion with categorization or data interpretation was resolved by discussion among research group members under the supervision of the PI.

\section{Results}

Out of the 33 documents included for analysis, two were systematic reviews, nine were reviews, and 16 primary research papers. Two blogs and four reports identified through manual search were also included. Corruption related documents dealt with the types, causes and consequences of corruption while governance-related documents mostly focused on decentralization, e-governance, and the concept of 'good governance'. Only six of the documents reviewed dealt with the issue of accountability as an essential element of good governance. Interestingly, literature fulfilling the search criteria for selected countries were limited in number, and the majority of relevant documents were from India. Given the wide prevalence of corruption in these countries (Bangladesh, Bhutan, India, Indonesia, Nepal, Sri Lanka, Myanmar, Vietnam, Philippines) [19], the relatively small number of published materials in these countries suggest a substantial evidence gap in this area which hamper the design of informed interventions for its containment. To further enhance the depth, breadth and richness of the study findings, researchers developed and analysed relevant sub-themes and then grouped these into two key study themes namely, Corruption (Table 4) and Governance (Table 5), and are presented below.

\section{'Corruption'}

In our review, a long list of irregularities and rulebreaking or rule-bending practices (i.e., 'corruption') were identified in the context of health care service delivery transactions including informal payments, bribery and absenteeism (Table 4).

\section{Informal payment}

In the reviewed literature, examples of informal payments include payments made at different stages of service use in the public health facilities ranging from availing a trolley for patient transport to getting admission and securing a hospital bed to availing subsidized medicines from the hospital. Even if admitted, patients and attendants were afraid that without extra payment (to mainly non-technical staff), they would either receive no treatment at all or would be subjected to neglect/ slow treatment, as they had no connection to or recommendation from, influential people [29]. Furthermore, financial barriers and patient frustration arising from petty corruption may work to hinder access and utilization of public sector facilities [30]. For example, only $24 \%$ of households in Pakistan visited Government Public Health facilities in 2004, while $45 \%$ consulted private medical practitioners. Similarly, in Bangladesh, only 
Table $\mathbf{3}$ Themes and sub-themes for framework analysis

\begin{tabular}{lll}
\hline Themes & Sub-themes & Example of codes used \\
\hline Corruption & - Different forms of corruption & - Bribery, informal payment, absenteeism, medicine irregularities \\
& - Corruption practices & - Administrative practice, pharmaceuticals, diagnostic practice, service delivery \\
& - Conditions that incentivize corruption & related practice \\
& - Impact of corruption and organizations that & - Medical education, career prospect, informal payment \\
promote corruption & - Use of resources, access \& utilization of services,
\end{tabular}

$10 \%$ of households visited government health care facilities, while health care-seeking from nongovernment organization (NGO) clinics increased from 30 to $49 \%$ of household in 2003. For those who do avail services, many feel trapped and forced to make these payments. The literature identifies social audits as a potentially effective method for revealing petty corruption at service delivery points including the practice of informal payments [30]. However, in some resource-poor settings such as Pakistan, Bangladesh, India, Cambodia and Vietnam, informal payments are viewed as a necessary source of financing health care and thus are rationalized and sustained within individual and organizational norms and practices [31]. Given the complexity and sensitivity of the practice, the literature recommends that information on informal payment is best elicited through self-administered questionnaires with anonymity [32].

\section{Bribery}

Bribery is found to have a negative correlation with health outcomes in Vietnam including enrollment in health insurance programmes [33]. Again, in Vietnam, advice on choice of hospitals from social interactions with friends and relatives has been shown to increase the propensity of bribes to hospital staff and the size of the bribe amount [34]. Bribery has also been found to reduce immunization coverage, delay newborn vaccination, and thus discourage use of public sector health services in the Philippines' [35]. In Bangladesh, the more remote the location, the greater the size of the bribe [36]. Here, bribery also occurs when recruiting doctors and in decisions regarding posting and transfer to a facility or region of choice [37]. In addition, practices like paying-off management authorities for taking unlawful leave, stealing government revenues such as patient registration fees, taking the salary of a deceased or "ghost" worker, and making false bills for events like training that didn't occur or in which the incumbent didn't participate, are common across the region [36, 37].

\section{Absenteeism}

Reports of widespread absenteeism and negligence were common across the papers in this review. Absences from work without leave were most commonly reported among doctors in the public sector, followed by lab technicians and nurses [28, 38, 39]. In a district in southern India, it was found that around $30 \%$ of medical doctors were absent on the day of survey (in 30 selected community health centres) [28]. Only $19 \%$ of them were present at all times, although many reported making arrangements with other doctors so that patients were not left unattended. In urban community health centres in Indonesia (9 in a city in Sumatra), $26 \%$ of the doctors were absent [38]. In a review of absenteeism in developing countries in 2006, absenteeism was found to vary from 40 to $50 \%$ in LMICs of south/south-east countries (India, Bangladesh, Indonesia) [39]. Moreover, regulatory regimes to manage absenteeism are weak and fragmented, and alignment or coordination with laws related to various aspects of health is lacking [40]. Of further concern is the negative impact of absenteeism on the extent to which service seekers trust the health system, and its disproportionate effects on the disadvantaged whose access to health care is already compromised [41].'Dual practice' by health professionals is quite common in south/south-east Asia and its poor regulation also encourages absenteeism [42].

\section{Underlying causes and consequences of corruption}

The underlying causes of irregularities and informal practices emerging from our review were predominantly financial including poor salary and benefits, lack of/poor incentives, lack of autonomy of local authorities to hire and fix remuneration, and lack of accountability of doctors to local authorities [30, 32, 33, $36,38,39]$. The impacts of corruption are multiple, affecting service access, utilization and cost. Corruption practices associated with the misuse of available resources in resource-constrained settings and increased financial burden on the poorest [30], also lead to inefficient public expenditure [32]. Corruption can increase the cost of treatment to patients if a bribe is demanded or an informal payment is made in addition to the official payment, and thereby reduces demand for services and worsen health outcomes [35]. Other effects include failure to ensure timely and appropriate treatment care for those who can 
Table 4 Summary of studies exploring different dimensions of 'corruption' ( $n=15)$

\begin{tabular}{|c|c|c|c|c|}
\hline $\begin{array}{l}\text { Author; year } \\
\text { [ref] }\end{array}$ & Type of study & Settings & $\begin{array}{l}\text { Themes/sub- } \\
\text { themes }\end{array}$ & Findings \\
\hline $\begin{array}{l}\text { Mannan MA; } \\
2013 \text { [29] }\end{array}$ & $\begin{array}{l}\text { Survey using both } \\
\text { quantitative and } \\
\text { qualitative methods }\end{array}$ & $\begin{array}{l}\text { Nationally representative sample from seven } \\
\text { divisions included } 14 \text { district and } 28 \text { sub- } \\
\text { district hospitals and } 28 \text { union hospitals in } \\
\text { Bangladesh }\end{array}$ & $\begin{array}{l}\text { Informal } \\
\text { payment/ } \\
\text { hospital } \\
\text { admission }\end{array}$ & $\begin{array}{l}\text { - Informal payments to facility staff (mainly non- } \\
\text { technical) hastened the process of getting admis- } \\
\text { sion in a public health facility } \\
\text { - About } 1 / 3 \text { rd of inpatients in district hospital and 1/ } \\
5 \text { th in sub-district hospitals made an extra pay- } \\
\text { ment for getting admission; } 8 \% \text { of them made } \\
\text { extra-payments at least three times and occurred } \\
\text { more for the poor as they had no connection to } \\
\text { or recommendation from influential people } \\
\text { - In FGDs, } 50 \% \text { of the participants said that they } \\
\text { made informal payments because they feared that } \\
\text { without these extra payments' they would either } \\
\text { receive no treatment at all or would be subjected } \\
\text { to neglect/slow treatment. }\end{array}$ \\
\hline
\end{tabular}

Paredes-Solís Mixed methods et al.; 2011

[30]

Lewis M; Review

2007 [31]
Stepurko et al.; 2010 [32]

Matsushima M \& Yamad H; 2016 [33]
South Asia (and Africa and Europe)

Informal payment/ impact
- It causes disproportionate financial burden to the poor households due to paying for supposedly free services and non-availability of medicines in hospitals

- Impact: Thus, dissatisfaction with services ultimately results in gradual decrease in the use of government services over time

- Social audits may be an important tool to identify corruption at service delivery points such as informal payments

Informal payment/ causes and impact

- Informal payment is quite common in south/ south-east Asia e.g., Pakistan (96\%), Bangladesh (60\%), India (24\%), Cambodia (55\%), Vietnam (81\%). - Causes: Low pay, irregular salary payments, poor governance and management

- Impact: Increases inequity in access to health care services.

39 countries including LMICs Informal payment research methods and instruments

Cross-sectional study; household survey

Ho Chi Minh city and Hanoi, Vietnam

Bribery/ causes and impact

- Methodologically, self-administered questionnaires were found to be suitable in a face-to-fact interview for collecting information of sensitive nature such as informal payment

- Bribery is common in instances such as enrolling members in health insurance schemes, provision of certain services, bypassing queue to reduce waiting time, transfer and posting of choice, taking unlawful leave etc.

- Bribery is negatively correlated with health

outcomes and insurance coverage

- Causes: Hospital directors' autonomy regarding staff hire and fire, salary and perks, transfer and promotion etc. health care workers sell services at higher prices

- Impact: Increased price of services

Nguyen VH; Survey Data

36,000 Households in Vietnam

Bribery

- Social interactions in the form of advice on choice of a hospital for a particular service leads to an increase in the propensity to bribe and the amount of bribe.

Bribery/ • Bribery reduces immunization coverage, delays

1100 households and 160 health workers Bribery/ from 80 municipalities in 19 provinces of impact

\&Gurgu, $T$

Quantitative Survey Philippines newborn vaccination, increases waiting time and discourages public health series

- Impact: Bribe increase the cost to consumers which reduces demand for services, reduces Government resources allocated to service delivery, affects health outcome in the rural areas

- Affects of corruption vary by region (rural or urban), and also, affects the poor disproportionately
- $41 \%$ patients pay illegal consultation fees in public sector health facilities; patients who were living further away from the health facilities, were paying more bribe

- Causes: Low payment of health care workers and lack of incentives 
Table 4 Summary of studies exploring different dimensions of 'corruption' ( $n=15)$ (Continued)

\begin{tabular}{lll}
\hline $\begin{array}{l}\text { Author; year Type of study } \\
\text { [ref] }\end{array}$ & Settings & $\begin{array}{l}\text { Themes/sub- } \\
\text { themes }\end{array}$
\end{tabular}

[ref]

Azad A; 2014 [37] sector)

selected Community Health Centers (CHCs) in South Karnataka
Ramadhan and Santoso; 2015 [38]
Quantitative survey
Indonesia

LMICS
5000 household survey in 52 districts govt. facilities in Bangladesh

\section{Bangladesh}

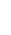

- Impact: Patients have to wait for a long time to get the service, the Quality of Care of services provided was low for non-bribing patients.

Bribery/ - Bribe was paid during recruitment of ad hoc impact doctors, 3rd - 4th class employees, transfer posting from Upazila to capital etc. - Doctors earned money from commission agreements with diagnostic centers thereby driving up costs of care etc.

Absenteeism/ • Unauthorized absence is more prevalent among causes and doctors (27\%), followed by lab technicians (17\%) impact and female nurses (13\%); mostly in the afternoon and around weekends (17\%); $76 \%$ of doctors were engaged in private practices or running their clinics

- Causes: More senior health workers having good relationship with higher authority leads absenteeism in the government facilities, lack of sufficient number of staff and residential facilities for doctors and nurses

Absenteeism/ • Unauthorized absence is found to be $26.5 \%$ causes and among Doctors, followed by $23 \%$ among impact midwives and 23\% among para-medics - Causes: Most of the doctors are living in city areas, and they leave facilities early, especially on the last working day.

- Impact: the poor and disadvantaged cannot receive appropriate and timely treatment

Absenteeism/ Absenteeism rate among health workers was 19\% causes and (Papua New Guinea) to 75\% (Bangladesh)

impact - Causes: Low wages and irregular payments of wages forced workers to indulge in additional income-earning activities which causes absenteeism in the government health facilities

- Impact: interference in service delivery, both quantitatively and qualitatively

Absenteeism - Absenteeism rates in primary health care centres in Bangladesh to be as high as 35\%

- The regulatory framework for monitoring health service delivery is weak, with 45 separate laws related to various aspects of health

Absenteeism/ . 42\% of the patients encountered corruption while Negligence accessing services and $43 \%$ faced negligence by professionals, disproportionally affecting the poorest disproportionately

- Impact: Lack of trust in health care providers and ultimately lesser use of services by the poor and the disadvantaged

Absenteeism/ - 'Dual practice' by health professionals is quite dual practice common in south/south-east Asia (e.g., in Bangladesh it is cited to be around $80 \%$ while in Indonesia from 70 to $80 \%$ )

- Poor regulation of dual practice encourages absenteeism and negatively affects access, quality and equity of services provided least afford costly services from the private sector [38], and wastage of resources [39].

\section{Governance}

Table 5 summarizes findings from the review of included papers (again, the majority from India and Bangladesh) related to the role of governance in curbing corruption. These are presented below under different sub-titles.

\section{Transparency and accountability}

Findings reveal that governance failure may occur due to an absence of long-term vision and planning, lack of a functioning regulatory regime, and limited attempts to assess performance of anti-corruption measures. This is 
Table 5 Summary of studies exploring different dimensions of 'Governance' $(n=18)$

\begin{tabular}{|c|c|c|c|c|}
\hline $\begin{array}{l}\text { Author, year } \\
\text { (country) }\end{array}$ & Type of study & Settings & $\begin{array}{l}\text { Themes/sub- } \\
\text { themes } \\
\text { covered }\end{array}$ & Findings \\
\hline $\begin{array}{l}\text { Rose J et al., } \\
2014 \text { [43] }\end{array}$ & Systematic review & $\begin{array}{l}\text { Bangladesh health sector since } \\
2000\end{array}$ & $\begin{array}{l}\text { Transparency } \\
\text { /accountability: } \\
\text { public sector }\end{array}$ & $\begin{array}{l}\text { - Some pertinent governance issues included } \\
\text { corruption of inventory management, high rate } \\
\text { of absenteeism of health care service providers } \\
\text { and problems of human resource management } \\
\text { - There is limited transparency in government } \\
\text { regarding basic data e.g., procurement } \\
\text { procedures at the national level } \\
\text { - public doctors unnecessarily refer patients to } \\
\text { private clinics or practices. }\end{array}$ \\
\hline
\end{tabular}

Nurunnabi M Survey and Secondary and Islam SK, research 2011 [44]

Ghimire, J

et al.; 2013

Qualitative study

$[45]$

Dieleman, M Review of case studies et al.; 2011

[46]

Kamal S et al.; Qualitative study using In2014 [47] depth interviews, KIl group discussion and secondary data

Garimella, S Case studies on posting and Sheikh, $\mathrm{K}_{i}$ and transfer 2016 [48]

Cleary, $\mathrm{S}$ et al.; Descriptive literature 2013 [49] review

Papp, S et al.; Case study 2013 [50]
533 patients from 45 hospitals in Dhaka city of Bangladesh were surveyed using questionnaire

90 health facilities in Siraha, Bardiya and Doti districts in Nepal

A literature review of $\mathrm{HRH}$ management in LMICs; case studies identified through Scopus, PubMed, Embase

Public and private health care institutions in Bangladesh

HRH

Transparency/ accountability: private sector

- In the private health care sector, four factors were found to be significantly associated with accountability, in order of influence: professionals, administration and management, legal enforcement and ethics, and government

Transparency - Only 49 (54\%) of the health facilities have /accountability: properly displayed signboard, 42 (47\%) citizen display of charter, $36(40 \%)$ free health services and information Information on Aama program in 25 (28\%) health facilities.

. 72 out of 90 health facilities have not displayed social audit reports, and 80 (89\%) of the health facilities have not maintained complaint box.

Transparency $\quad$ - The review covered four dimensions of /accountability: governance: performance, equity and equality, managing $\mathrm{HRH}$ partnership, and oversight

- In 'oversight,' local-level corruption affects accountability and local-level trust in governance

- Experiences with accountability mechanisms for HRH policy development and implementation were lacking.

Transparency $\quad \cdot 20 \%$ of total sanctioned post is vacant. Doctors /accountability: do not have to be accountable for not $\mathrm{HRH}$ attending the office on time.

- The procedures of promotion, selection grade, and regularizing 'In Charge' positions are quite lengthy in the health sector.

- Political pressures and influences are very prevalent when medical certificates on death and injuries are badly needed for filing police cases.

Primary health care center in Tamil Transparency Nadu, India

/accountability: $\mathrm{HRH}$

- Posting and transfer emerge as a complex phenomenon, shaped partially by the laws of the state and partially as a parallel system of norms and incentives requiring consideration and coordination of the interests of different groups.

- Beyond a functional perspective of PT, it also reflects justice and fairness as it plays out in the health system.

Review of PubMed literature in LMICS

Accountability:

citizen participation

- Bureaucratic accountability mechanisms often constrain the functioning of external accountability mechanisms.

- Citizen participation: community members are behaving like "watchdogs;" external supervision by community people can play a role for functioning external accountability mechanism.

Accountability: - Public hearings as a social accountability tool citizen participation facilitate: (1) demand generation for better services, (2) leveraging intermediaries to legitimize demands of poor and marginalized women, and (3) sensitizing leaders and health care providers to women's needs 
Table 5 Summary of studies exploring different dimensions of 'Governance' $(n=18)$ (Continued)

\begin{tabular}{lll}
\hline $\begin{array}{l}\text { Author, year Type of study } \\
\text { (country) }\end{array}$ & Settings & $\begin{array}{l}\text { Themes/sub- Findings } \\
\text { themes } \\
\text { covered }\end{array}$ \\
\end{tabular}

\begin{tabular}{|c|c|c|}
\hline $\begin{array}{l}\text { Roalkvam, S; } \\
2014 \text { [51] }\end{array}$ & Review & India \\
\hline $\begin{array}{l}\text { Lodenstein, E } \\
\text { et al.; } 2017 \\
\text { [52] }\end{array}$ & Review & $\begin{array}{l}37 \text { social accountability initiatives } \\
\text { in LMICs identified through a } \\
\text { literature search }\end{array}$ \\
\hline
\end{tabular}

- The process involves raising critical

consciousness among marginalized women and giving space to voice their concerns and demands to people in power and also, receptivity of the latter to hear their grievances and act on these

Accountability: - Rights of citizens are not solely contingent citizen upon the existence of legally guaranteed rights participation but also significantly on the social conditions that make their effective exercise possible.

Accountability: - Perspectives of providers to citizen's citizen expectations and demands for better health participation care is essential for improving the quality of primary health care in different settings - Providers' 'receptivity' to such demands expectations and their 'relation' to citizens for tapping personal and professional support for improved responsiveness can be understood and acted upon following a ContextMechanism-Outcome theory of change

Islam MS and Mixed method using case Muradnagarupazila health Ullah MW; study approach

2009 [53]

Regmi, K et al.; Review 2010 [54]

Panda, B, and Review

Thakur, $\mathrm{H}$;

2016 [55]
Muradnagarupazila health
complex, Comilla, Bangladesh

Medline, PubMed, Embase, CINAHL, DARE literature review from Nepal
Focused literature review from India using PubMed and Google Scholar

28 districts
Quantitative study

and Tuladhar

S; 2013

(Nepal) [56]
Rauniyar G

et al., 2013

[57]
Performance Evaluation report
Indonesia; evaluation of ADB funded decentralized health services project
Accountability: - Peoples' have no involvement in decision citizen making process in the health sector

participation $\quad$ Lack of proper economic management is hampering the participation of people in health services.

Decentralization • Decentralization of health sector implies increased accessibility of the public to health services by increasing transparency and accountability

- The restructuring of the district health care services from decentralization was considered the highest achievement for meeting the needs of the local community.

- Decentralization is diverting the attention of the public away from central bureaucratic rules and gained popularity by installing local governments at the lower level.

Decentralization · For exploring effects of decentralization, one needs to examine and assess the role and functions of local decision-making institutions and results thereof at institutions, systems, and individual levels

- Decentralization of local self-governance in public health sector has multiple dimensions in conceptualization, measurement complexities, and byproducts for consideration.

Decentralization • Local health facility management committee ensured community engagement, mobilization of local resources, improved responsiveness and accountability to the community, and provision of inclusive health services - Availability of technical staff, supervision, and monitoring, and display of citizen charter improved accountability.

Decentralization - Improved access to health care services, especially in remote and rural areas; the poor benefitted the most

- Service delivery constrained by limited funding with a major proportion spent on administration

- Continuous monitoring is essential for identifying current trends of decentralization 
Table 5 Summary of studies exploring different dimensions of 'Governance' $(n=18)$ (Continued)

\begin{tabular}{|c|c|c|c|c|}
\hline $\begin{array}{l}\text { Author, year } \\
\text { (country) }\end{array}$ & Type of study & Settings & $\begin{array}{l}\text { Themes/sub- } \\
\text { themes } \\
\text { covered }\end{array}$ & Findings \\
\hline $\begin{array}{l}\text { Millington KA } \\
\text { and Bhardwaj } \\
\text { M; } 2017 \text { [58] }\end{array}$ & Report & LMICs including India, Bangladesh & $\begin{array}{l}\text { Good } \\
\text { governance }\end{array}$ & $\begin{array}{l}\text { - To address corruption in pharmaceutical } \\
\text { procurement, drug pricing transparency is } \\
\text { mandatory for good governance through drug } \\
\text { pricing information from a govt. online } \\
\text { database. }\end{array}$ \\
\hline $\begin{array}{l}\text { Roncarati, M; } \\
2010 \text { [59] }\end{array}$ & Review of examples & LMICs & $\begin{array}{l}\text { Good } \\
\text { governance }\end{array}$ & $\begin{array}{l}\text { - Weak institutional capacities hinder good } \\
\text { governance and better health outcome. } \\
\text { - Generate awareness among stakeholders, } \\
\text { supportive institutional structures, incentives } \\
\text { and payment schemes enhance good } \\
\text { governance }\end{array}$ \\
\hline $\begin{array}{l}\text { Huss, R et al.; } \\
2010 \text { (India) } \\
{[60]}\end{array}$ & $\begin{array}{l}\text { Qualitative study/ } 44 \text { semi- } \\
\text { structured interviews }\end{array}$ & $\begin{array}{l}\text { Government hospitals in urban } \\
\text { and rural areas of Karnataka; }\end{array}$ & $\begin{array}{l}\text { Good } \\
\text { governance }\end{array}$ & $\begin{array}{l}\text { - Good governance is the responsibility of all } \\
\text { citizens for a responsive and inclusive health } \\
\text { systems with fair outcomes } \\
\text { - To combat corruption effectively, committed } \\
\text { and powerful leadership, adequate resource } \\
\text { and capacity to investigate senior government } \\
\text { officials, and institutional reforms are needed } \\
\text { - Concerted efforts from political and justice } \\
\text { systems, media and awareness-building among } \\
\text { the population is essential to succeed in anti- } \\
\text { corruption actions }\end{array}$ \\
\hline
\end{tabular}

especially apparent in the lack of effective accountability mechanisms guiding both private and public health care sectors in Bangladesh [43, 44]. Dissemination of relevant information to the public is lacking which contributes to the public not being properly informed about what services are available, at what cost, and when. For example, in a qualitative study of three districts in Nepal, only $54 \%$ of the health facilities were found to have a properly displayed signboard, $47 \%$ displayed a citizen charter, and $40 \%$ displayed information about free health care services [45]. Moreover, the process of HRH management lacks transparency in LMICs such as India and Indonesia, thereby affecting accountability and trust in the system $[46,47]$. In the public sector, about $1 / 5$ th of the sanctioned posts in Bangladesh remain vacant, however, the posted doctors seem to be indifferent regarding attendance [48].

\section{Citizen's voice}

One way to rectify the weak system of accountability is to adopt demand-side strategies such as increasing the engagement of the citizens and raising their voices as "watch dogs" to claim rights to quality health care services [49, 50]. This may take various forms with varying degrees of effectiveness such as making service providers explain their activities in 'public hearings' as has been observed in India [51]. Public hearings as an accountability mechanism have potential to raise critical consciousness among disadvantaged groups such as poor women, and provide a floor in which they can raise their concerns. Better communicating and reconciling provider and citizen expectations is also important, helping improve the Quality of Care [52]. For this process to succeed, fiscal space at the local level is also necessary [53].

\section{Decentralisation}

In the reviewed literature from Nepal [54] and India [55], decentralization has been advocated as an effective measure to ensure and enhance transparency and accountability at the local level in a manner that addresses community's needs and priorities. In Nepal, it has been shown to improve access to, utilisation of, and management of health care services [54]. Additionally, suggestions have been made to measure its effects in multiple dimensions while evaluating health outcomes in India [55]. Another qualitative paper from Nepal draws attention to elements such as the roles, rights and responsibilities of both citizens and local institutions in the decentralizing process [56], and how resource constraints at the local level may negatively impact service delivery as has been seen in the case of Indonesia [57].

\section{Good governance}

Finally, some of the literature sheds light on what constitutes good governance and what needs to be done to achieve it. For example, the use of information technology (IT) is suggested to reduce corruption in public transactions such as procurement of medical supplies as have been observed in India and Bangladesh [58]. On the other hand, insufficient institutional support can 
undermine people's participation which is a crucial parameter of good governance. Administrative factors, bureaucratic norms, and motivational patterns are also emphasized as important determinants. In Bangladesh, good governance initiatives are limited and social accountability remains elusive [59]. Achieving good governance for health is the responsibility of citizens as well as political leadership. It requires concerted actions by the justice system and a committed media to mobilise necessary commitments as shown in India [60].

\section{Regulatory regime}

Over the last 12 years, attempts have been made to develop policies to contain corruption in the studied LMICs of the south and south-east Asian region. (Table 6). The six countries in this review signed and adopted the 'United Nation Convention against Corruption (UNCAC)' and initiated activities to comply with the Convention [69]. The Right to Information Act (RTI) has also been passed in Bangladesh [61], India [62] and Nepal [63] and Sri Lanka [64], however, implementation remains a challenge. In Bangladesh, for example, the RTI Act has been in place since 2008, yet $29 \%$ of citizens continue to face difficulties in accessing information, and $8 \%$ reportedly paid bribes to access information [61]. Part of this failure in implementation relates to lack of awareness about the legislation due to insufficient promotion by the government. The Whistle Blower Protection Act has been passed in Bangladesh [65] and India [66] in 2014, however, due to inadequate power of law-enforcing agencies to investigate complaints and impose penalties, implementation has been partial. This is also true for the Ombudsman act [67] and the prevention of corruption act (amendment) to punish bribery [68], both by India.

\section{Discussion}

This scoping review identified different forms of corruption and its practices among health care providers delivering frontline (PHC) services in selected south/ south-east Asian LMICs. Our findings reveal important insights regarding the types, causes, consequences and structural dimensions of such practices as they relate to health outcomes, especially for the poor and disadvantaged. We also reflected on the governance and regulatory arrangements in these countries, and

Table 6 Summary of policies related to prevention of corruption in the LMICs of south and south-east Asian countries

\begin{tabular}{|c|c|c|}
\hline $\begin{array}{l}\text { Country, year } \\
\text { (Ref) }\end{array}$ & Name of policy & Key feature \\
\hline $\begin{array}{l}\text { Bangladesh, } \\
2008 \text { [61] }\end{array}$ & Right to Information Act & $\begin{array}{l}\text { - Every citizen of Bangladesh shall have the right to information from the authority, and the authority } \\
\text { shall, on demand from a citizen, be bound to provide him with the information. } \\
\text { - Every authority shall prepare catalogue and index of all information and preserve it in an } \\
\text { appropriate manner. }\end{array}$ \\
\hline $\begin{array}{l}\text { India, } 2005 \\
{[62]}\end{array}$ & & $\begin{array}{l}\text { - An Indian citizen can apply for and obtain information held by any public authority, subject to } \\
\text { certain defined exceptions in respect of national interest, legislative privilege and right to privacy. }\end{array}$ \\
\hline $\begin{array}{l}\text { Nepal, } 2007 \\
{[63]}\end{array}$ & & $\begin{array}{l}\text { - Every citizen of Nepal shall have access to the information held in the public bodies. } \\
\text { - Protection of whistleblower: It shall be a responsibility of an employee of a public body to } \\
\text { provide information on any ongoing or probable corruption or irregularities or any deed taken as } \\
\text { offence under the prevailing laws. } \\
\text { - The whistleblower shall not be terminated from his/her post or punished with any legal } \\
\text { responsibility or caused any loss or harm for giving information. }\end{array}$ \\
\hline $\begin{array}{l}\text { Sri Lanka, } 2016 \\
\text { [64] }\end{array}$ & & $\begin{array}{l}\text { - An act to provide for the right of access to information; to specify grounds on which access may be } \\
\text { denied; to establish the right to information commission; to appoint information officers; to set out } \\
\text { the procedure and for matters connected therewith or incidental thereto. }\end{array}$ \\
\hline $\begin{array}{l}\text { Bangladesh, } \\
2011[65]\end{array}$ & $\begin{array}{l}\text { The Whistle Blower } \\
\text { Protection Act }\end{array}$ & $\begin{array}{l}\text { - If any whistleblower discloses any authentic information, his identity cannot not be divulged } \\
\text { without his consent. } \\
\text { - For making disclosure of public interest information, no criminal or civil, or departmental suit can be } \\
\text { filed against the whistleblower. } \\
\text { - If the whistleblower is a service holder, only for disclosing public interest information- demotion, } \\
\text { harassment transfer or forced retirement or any other measures cannot be taken against him that } \\
\text { would incur loss of his psychological, financial or social standing or no departmental actions can be } \\
\text { taken against him or he cannot be treated discriminatorily. }\end{array}$ \\
\hline $\begin{array}{l}\text { India, } 2014 \\
{[66]}\end{array}$ & & - Establish a mechanism to safeguard persons who make a complaint regarding an act of corruption \\
\hline $\begin{array}{l}\text { India, } 2013 \\
{[67]}\end{array}$ & Lokpal and Lokayuktas Act & $\begin{array}{l}\text { - Lokpal and Lokayuktas bodies have been empowered to investigate allegations of corruption } \\
\text { against public functionaries. } \\
\text { - The jurisdiction of the Lokpal (Ombudsman) includes the prime minister, ministers, members of } \\
\text { parliament and other public servants. }\end{array}$ \\
\hline $\begin{array}{l}\text { India, } 2013 \\
{[68]}\end{array}$ & $\begin{array}{l}\text { Prevention of Corruption } \\
\text { (amendment) Bill }\end{array}$ & $\begin{array}{l}\text { - The Amendment Bill include the offense of passive bribery, its various aspects including solicitation } \\
\text { and acceptance of bribe through intermediaries (private persons). }\end{array}$ \\
\hline
\end{tabular}


the need for innovative measures for curbing corruption and improving governance, given the largely ineffective traditional (top-down) approaches [70]. The implications of these findings for achieving UHC by 2030 in the context of sustainable development goals (SDGs) are discussed.

The 'pandemic' of corruption in frontline health care service delivery is threatening the global goal of achieving UHC by 2030 and health-related SDGs [71]. It is responsible for an estimated loss of over US $\$ 500$ billion every year, more than what is needed to implement UHC globally. LMICs in the south/south-east Asia region are no exception. Despite its cost to people and health systems in these countries, there exists substantial evidence gaps as shown by the relative scarcity of relevant literature except for India (and to some extent, Bangladesh) which provided the majority of the reviewed papers. This may be due to factors such as the sensitive nature of the topic, a consensus high up in the sector to maintain the 'dirty secret,' the 'political correctness' of pursuing the issue [72] and last but not the least, the methodological challenges of doing research on corruption [73].

The different forms and dimensions of corruption in south/south-east Asian countries revealed in this study are not new [73, 74]. Whether the corruption is 'petty' or not, the cumulative impact on health outcomes is damaging, and affects the equity, quality and responsiveness of the services delivered. Another important consequence of corruption is the erosion of 'trust' in the system which reduces utilization and undermines actions to 'prevent, detect and respond' to major health crisis such as seen in case of Ebola [75]. Whatever the form and dimension of corruption, a main driver is the ubiquitous financial and structural problem of not offering appropriate incentives (monetary and non-monetary) to motivate the frontline health care providers. Irregularities are further enabled by weak health system characterized by poor governance e.g., poor supervision, victim-blaming, concentration of responsibilities and authorities at the centre, and almost no transparency and accountability [70, 71].

Our review also found substantial gaps in the implementation of the traditional 'top-down' measures for containing corruption, resulting in substantial costs for health systems and health service recipients. Some of the existing laws and policies we documented (Table 6) were inconsistent with international standards. One of the reasons may be that the discretion and freedom enjoyed by the frontline providers (as 'street-level bureaucrats') [76] in a weak health system encourage them to bend the rules and laws in their favour, and make centrally designed anti-corruption measures largely in-effective. In extreme cases, communities may retaliate by imposing 'rude accountability' through social norms and actions that force the providers to deliver services [77].

\section{What are the alternatives?}

The 'failure' of traditional measures to contain corruption compels those at high levels of policy and practice to look elsewhere for a new vision which embraces innovative, demand-side, and community perspectives [23]. Whatever the approach adopted, it is essential that health care providers are held accountable to service users, and that systems and providers enable service responsiveness, quality and affordability for better health outcomes [78]. In order to amplify the 'voice' of the community, measures are needed that raise awareness about service entitlements and enable complaints to be received and addressed within a reasonable timeframe [79]. It is also imperative that corruption mitigation efforts be comprehensive (multi-pronged and multisectoral) and not stand-alone; that they focus on the most harmful practices first and are grounded in grassroots realities; that engage and empower the community and get their buy-in; and be part of a wider health systems reforms to achieve UHC [71].

It is encouraging to note that in a number of countries a variety of innovative bottom-up, and communitybased, demand-side interventions are being tested to curb the harmful effects of corruption and make the system more accountable. Examples include: patients' welfare committees and hospital management societies ensuring responsible use of funds and the provision of quality services in India [80]; primary health care (PHC) management committees that actively engage the community in improving quantity and the quality of services in Nepal [56]; and community monitoring of service provider's attendance at facilities, especially by women who are the major consumers of the frontline services in Bangladesh [81] and public hearings to voice community's grievances with health care services and demand remedial measures, again in Bangladesh [82]. However, until and unless these small-scale, local-level experiments are taken to scale, in combination with more effective and efficient traditional regulatory approaches, curbing corruption in the delivery of frontline PHC services will remain elusive.

\section{Limitations}

The search engine used for this scoping study was limited to PubMed, SCOPUS and Google Scholar databases and grey material search to institutional and government websites through Google, due to constraints in time and resources. Only articles and documents in English were searched. We limited our search to the delivery of health care services only and did not include other major areas of health sector corruption such as pharmaceutical 
procurement and construction of infrastructure. The study would have benefited from perspectives and experiences of the key actors involved at the top levels which was not logistically possible.

\section{Implications}

Interestingly, the countries studied are characterized by low levels of GDP, low levels of education, low levels of democratic values (e.g., freedom of press, speech and congregation etc.) in the political system, and societies organized along strong patriarchal norms. All of these may act as barriers to reduce corruption in these countries [76]. To tackle this situation, a two pronged strategy is recommended: alleviating the socioeconomic, normative and cultural barriers as mentioned above but at the same time, testing community-based, innovative micro-level interventions (such as public hearings, community monitoring of attendance of the health care providers etc.). This will help in the creation of a win-win situation for frontline health care workers as well as vested socio-political interests through improvement of community health and well-being and thereby goodwill for those in power who otherwise benefit from maintaining the status quo. Further research is needed to develop and refine such innovations on the ground and to test the feasibility of scaling up the successful ones. Being a sensitive issue, the methods for research on 'corruption' also need re-thinking regarding how the key actors of corruption can be challenged and engaged in divulging sensitive information without repercussion.

\section{Conclusions}

Corruption is "embedded" in the health sector [83] and is an open secret [84]. It undermines the development of a pro-poor, equitable and inclusive health system essential for achieving UHC by 2030. This study is first of its kind to document the levels, extents, causes and consequences of corruption in the health sector in the selected LMICs of the south and south-east Asian region. In addition, it explored alternative, bottom-up ways of combating health sector corruption which might guide future activities in this area to improve population health outcomes. Evidently, 'business as usual' will not do and given the limitation of traditional measures of containing corruption, strategic 'out of box' thinking will be needed. The historic opportunity provided by the SDGs should be seized, and used to push the UHC agenda forward. In the process, it is essential that key players in and around frontline service delivery points are not antagonized, that community is engaged, and that intervention(s) are in alignment with the prevailing political settlements such that efforts towards curbing corruption at the grassroots (e.g., PHC services) are embraced and sustained [85].

\section{Supplementary information}

Supplementary information accompanies this paper at https://doi.org/10. 1186/s12889-020-08975-0.

Additional file 1. Preferred Reporting Items for Systematic reviews and Meta-Analyses extension for Scoping Reviews (PRISMA-SCR).

\section{Abbreviations \\ AMR: Antimicrobial Resistance; IT: Information technology; ICTs: Information and Communications Technology; LMICs: Low- and Middle Income- Countries; NGO: Non-GovernmentOrganisation; PRISMA: Preferred Reporting Items for Systematic Reviews and Meta-Analysis; PHC: Primary Health care; RTI: Right to Information; SDGs: Sustainable Development Goals; \\ UHC: Universal Health Coverage; UNCAC: United Nation Convention against Corruption}

\section{Acknowledgements}

Authors acknowledge support from SamiunNazrinBente Kamal Tune, Senior Research Associate, BRAC James P. Grant BRAC School of Public Health, BRAC University for helping with organizing and formatting the references.

\section{Authors' contributions}

SMA and NN conceptualised and designed the study protocol. NN, RH and MSH collected and analysed data. SMA and NN interpreted data and drafted the manuscript. AMA and DB critically reviewed the manuscript and contributed substantially for its improvement. SMA and NN prepared the final version for submission. All authors read and approved the final version for submission.

\section{Funding}

The study received funding from the Department of International Development (DfID) (Reference No.RC01).

\section{Availability of data and materials}

All data relevant to the study are included in the article. Any additional data may be available from the corresponding author (SMA) on reasonable request.

Ethics approval and consent to participate

This study was approved by the ethics review committee of the BRAC JPG School of Public Health, BRAC University (Ethics Reference No. 2018-02 dated 14 January 2018)

\section{Consent for publication}

Not required.

\section{Competing interests}

None declared.

\section{Author details}

${ }^{1}$ BRAC James P. Grant BRAC School of Public Health, BRAC University, 5th Floor(Level-6), icddrb Building, 68 ShahidTajuddin Ahmed Sarani, Mohakhali, Dhaka 1212, Bangladesh. ${ }^{2}$ Department of Global Health and Development, London School of Hygiene and Tropical Medicine (LSHTM), Room TP 308, 15-17 Tavistock Place, London WC1H 9SH, UK. ${ }^{3}$ Department of Family Medicine, Faculty of Medicine, McGill University, 5858 Cote des Neiges, Room 332, Montréal, Québec H3S 1Z1, Canada.

Received: 20 October 2019 Accepted: 24 May 2020

Published online: 08 June 2020

\section{References}

1. Hogan DR, Stevens GA, Hosseinpoor AR, Boerma T. Monitoring universal health coverage within the sustainable development goals: development and baseline data for an index of essential health services. Lancet Glob Health. 2018;6(2):152-68.

2. Kutzin J, Sparkes SP. Health systems strengthening, universal health coverage, health security and resilience. Bull World Health Org. 2016;94(1):2. 
3. Lewis M. Governance and corruption in public health care systems. Center for Global Development Working Paper No. 78. https://www.cgdev.org/ sites/default/files/5967_file_WP_78.pdf. Accessed 24 Feb 2020.

4. Evans T, Whitehead $M$, Diderichsen $F$, editors. Challenging inequities in health: from ethics to action. New York: Oxford University Press; 2001.

5. Vian T. Review of corruption in the health sector: theory, methods and interventions. Health Policy Plan. 2008;23(2):83-94.

6. Factor R, Kang M. Corruption and population health outcomes: an analysis of data from 133 countries using structural equation modeling. Int J Public Health. 2015;60(6):633-41.

7. Transparency International (TI). 'Bangladesh: overview of corruption and anti-corruption with a focus on the health sector'. Berlin: Transparency International; 2015. https://www.u4.no/publications/bangladesh-overviewof-corruption-and-anticorruption-with-a-focus-on-the-health-sector. Accessed 24 Feb 2020

8. Mostert S, Sitaresmi MN, Njuguna F, van Beers EJ, Kaspers GJ. Effect of corruption on medical care in low-income countries. Pediatr Blood Cancer. 2012;58(3):325-6.

9. Hanf M, Van-Melle A, Fraisse F, Roger A, Carme B, Nacher M. Corruption kills: estimating the global impact of corruption on children deaths. PLoS One. 2011;6(11):e26990.

10. Witvliet MI, Kunst AE, Arah OA, Stronks K. Sick regimes and sick people: a multilevel investigation of the population health consequences of perceived national corruption. Tropical Med Int Health. 2013;18(10):1240-7. https://doi.org/10.1111/tmi.12177.

11. Hua LT, Noland RB, Evans AW. The direct and indirect effects of corruption on motor vehicle crash deaths. Accid Anal Prev 2010; 42(6): 1934-1942. https://doi.org/10.1016/j.aap.2010.05.015

12. Ciccone DK, Vian T, Maurer L, Bradley EH. Linking governance mechanisms to health outcomes: a review of the literature in low-and middle-income countries. Soc Sci Med. 2014;1(117):86-95.

13. World Bank. Strengthening World Bank group engagement on governance and anticorruption. http://documents.worldbank.org/curated/en /426381468340863478/pdf/390550replacement.pdf. Accessed 4 July 2019.

14. Makuta I, O'Hare B. Quality of governance, public spending on health and health status in sub Saharan Africa: a panel data regression analysis. BMC Public Health. 2015;15:932. https://doi.org/10.1186/s12889-015-2287-z.

15. Kim S, Wang J. Does quality of government matter in public health?: comparing the role of quality and quantity of government at the National Level. Sustainability2019;11(11): 3229. https://doi.org/10.3390/su11113229.

16. Hardoon D, Heinrich F. Global corruption barometer. UK: Transparency International; 2013. https://www.transparency.org/gcb2013.

17. Vian T. Corruption in the health sector. U4 anti-corruption training course. Bergen: U4 Anti-corruption Resource Centre, Chr. Michelsen Institute; 2011.

18. Hechanova MR, Melgar I, Falguera PZ, Villaverde M. Organisational culture and workplace corruption in government hospitals. J Pac Rim Psychol. 2014; 8(2):62-70.

19. Transparency International (TI). Fighting corruption in South Asia: Building accountability. Berlin: Transparency International; 2014. https://www. transparency.org/whatwedo/publication/fighting_corruption_in_south_asia_ building_accountability. Accessed 24 Feb 2020.

20. Ahmed SM, Evans TG, Standing H, Mahmud S. Harnessing pluralism for better health in Bangladesh. Lancet. 2013;382(9906):1746-55.

21. National Academies of Sciences, Engineering, and Medicine 2018. The critical health impacts of corruption (Chapter six). pp 203-26. In: Crossing the Global Quality Chasm: Improving Health Care Worldwide. Washington, DC: The National Academies Press. https://doi.org/10.17226/25152.

22. Liao MC, Lee MH. Corruption costs lives: a cross-country study using an IV approach. Int J Health PlannMgmt. 2016;31:175-90. https://doi.org/10.1002/ hpm.2305.

23. Hanna R, Bishop S, Nadel S, Scheffler G, Durlacher K. The effectiveness of anti-corruption policy: what has worked, what hasn't, and what we don't know-a systematic review. In: Technical report. London: EPPI-Centre, Social Science Research Unit, Institute of Education, University of London; 2011.

24. Gilson L. Lipsky's street level bureaucracy. In: Page E, Lodge M, Balla S, editors. Oxford handbook of the classics of public policy. Oxford: Oxford University Press; 2015.

25. Mackey TK, Kohler JC, Savedoff WD, Vogl F, Lewis M, Sale J, et al. The disease of corruption: views on how to fight corruption to advance 21st century global health goals. BMC Med. 2016;14(1):149.
26. Pluye $\mathrm{P}$, Hong QN. Combining the power of stories and the power of numbers: mixed methods research and mixed studies reviews. Ann Rev Public Health. 2014;18(35):29-45.

27. Cherecheş RM, Ungureanu MI, Sandu P, Rus IA. Defining informal payments in health care: a systematic review. Health Policy. 2013;110(2-3):105-14.

28. Nanjunda. Missing doctors? An investigative study on the absenteeism among medical workers in community health centers (CHCs) in rural South Karnataka, India. JLUMHS 2014;13(01):37-40.

29. Mannan MA. Access to public health facilities in Bangladesh: a study on facility utilisation and burden of treatment. Bangladesh Dev Studies. 2013; 36(4):25-80.

30. Paredes-Solís S, Andersson N, Ledogar RJ, Cockcroft A. Use of social audits to examine unofficial payments in government health services: experience in South Asia, Africa, and Europe. BMC Health Serv Res. 2011;11(2):S12.

31. Lewis M. Informal payments and the financing of health care in developing and transition countries. Health Aff. 2007;26(4):984-97.

32. Stepurko T, Pavlova M, Gryga I, Groot W. Empirical studies on informal patient payments for health care services: a systematic and critical review of research methods and instruments. BMC Health Serv Res. 2010;10(1):273.

33. Matsushima M, Yamada H. Impacts of bribery in health care in Vietnam. J Dev Studies. 2016:52(10):1479-98.

34. Nguyen $\mathrm{VH}$. Social interactions and the spread of corruption: evidence from the health sector of Vietnam. Montreal: Department of Economics, Concordia University; 2008. http://citeseerx.ist.psu.edu/viewdoc/ download?doi=10.1.1.495.6497\&rep=rep1\&type=pdf. Accessed 20 Feb 2020.

35. Azfar O, Gurgur T. Does corruption affect health outcomes in the Philippines? Econ Govern. 2008;9(3):197-244.

36. Abdallah W, Chowdhury S, Iqbal K. Corruption in the health sector: evidence from unofficial consultation fees in Bangladesh. 2015.http://ftp.iza.org/dp92 70.pdf. Accessed 24 Feb.2020.

37. Azad A. 2014. Health sector sickened with bribery and corruption (Blog). https://www.dhakatribune.com/uncategorized/2014/11/06/tib-health-sectorsickened-with-bribery-and-corruption. Accessed 24 Feb.2020.

38. Ramadhan AP, Santoso D. Health workers absenteeism: Indonesia urban public health centres. J Public Health. 2015;23(3):165-73.

39. Lewis MA. Tackling health care corruption and governance woes in developing countries. Washington DC: Center for Global Development; 2006.https://www.codev.org/sites/default/files/7732_file_ GovernanceCorruption.pdf Accessed 24 Feb.2020.

40. McDevitt A, Kelso C, Zaman I. Bangladesh: Overview of corruption and anticorruption with a focus on the health sector U4, 2015. https://www.u4.no/ publications/bangladesh-overview-of-corruption-and-anti-corruption-with-afocus-on-the-health-sector. Accessed 24 Feb. 2020.

41. Knox C. Dealing with sectoral corruption in Bangladesh: developing citizen involvement. Public Administration and Development. Int J Manag Res Prac. 2009;29(2):117-32.

42. Hipgrave DB, Hort K. Dual practice by doctors working in South and East Asia: a review of its origins, scope and impact, and the options for regulation. Health Pol Plan. 2013;29(6):703-16.

43. Rose J, Lane TM, Rahman T. Bangladesh governance in the health sector: a systematic literature review. 2014.http://documents.worldbank.org/curated/ en/366061468004785129/Bangladesh-governance-in-the-health-sector-asystematic-literature-review. Accessed 24 Feb. 2020.

44. Nurunnabi M, Kamrul IS. Accountability in the Bangladeshi privatized health care sector. Int J Health Care Qual Assur. 2012;25(7):625-44.

45. Ghimire J, Devkota A. Health governance at local level from human resource for health perspectives: the case of Nepal. J Nepal Health Res Counc. 2013;11(24):133-7.

46. Dieleman M, Shaw DM, Zwanikken P. Improving the implementation of health workforce policies through governance: a review of case studies. Hum Resource Health. 2011;9(1):10.

47. Kamal S, Iftekharuzzaman KS, Hassan M, Akram S. Governance challenges in the health sector and the way outs. Dhaka: Transparency International Bangladesh; 2014.

48. Garimella S, Sheikh K. Health worker posting and transfer at primary level in Tamil Nadu: governance of a complex health system function. J Fam Med Primary Care. 2016;5(3):663

49. Cleary SM, Molyneux S, Gilson L. Resources, attitudes and culture: an understanding of the factors that influence the functioning of accountability mechanisms in primary health care settings. BMC Health Serv Res. 2013;13(1):320. 
50. Roalkvam S. Health governance in India: citizenship as situated practice. Glob Public Health. 2014;9(8):910-26.

51. Papp SA, Gogoi A, Campbell C. Improving maternal health through social accountability: a case study from Orissa, India. Glob Public Health. 2013;8(4): 449-64.

52. Lodenstein E, Dieleman M, Gerretsen B, Broerse JE. Health provider responsiveness to social accountability initiatives in low-and middle-income countries: a realist review. Health Pol Plan. 2016;32(1):125-40.

53. Islam MS, Ullah MW. People's participation in health services: a study of Bangladesh's rural health complex. Virginia: Bangladesh Development Research Center (BDRC); 2009. http://www.bangladeshstudies.org/files/ WPS_no7.pdf. Accessed 24 Feb 2020.

54. Regmi K, Naidoo J, Greer A, Pilkington P. Understanding the effect of decentralisation on health services: the Nepalese experience. J Health Organ Manag. 2010;24(4):361-82.

55. Panda B, Thakur HP. Decentralization and health system performance-a focused review of dimensions, difficulties, and derivatives in India. BMC Health Serv Res. 2016;16(6):561.

56. Gurung $\mathrm{G}$, Tuladhar $\mathrm{S}$. Fostering good governance at peripheral public health facilities: an experience from Nepal. Rural Remote Health. 2013;13(2): 2042. Available from: https://www.rrh.org.au. Accessed 17 July 2019.

57. Rauniyar G, Lim P, Melo-Cabuang V. Decentralized Health Services Project in Indonesia: Performance Evaluation Report. https://www.adb.org/sites/ default/files/evaluation-document/36097/files/in15-14-0.pdf. Accessed 18 July 2019.

58. Millington K, Bhardwaj M. Evidence and experience of procurement in health sector decentralisation. 2017. https://assets.publishing.service.gov.uk media/59845568e5274a1707000065/108-Evidence-and-experiences-of-othercountries-health-procurement.pdf. Accessed 24 Feb.2020.

59. Roncarati M. Governance in the health-care sector: Experiences from Asia. NACC J, Special Issue. 2010;3(2). https://www.scribd.com/document/13904 0540/NACC-Journal-Special-Issue. Accessed 24 Feb.2020.

60. Huss R, Green A, Sudarshan H, Karpagam SS, Ramani KV, Tomson G, Gerein $\mathrm{N}$. Good governance and corruption in the health sector: lessons from the Karnataka experience. Health Pol Plan. 2010;26(6):471-84.

61. The Bangladesh Gazette. Right to Information Ordinance, 2008: Ordinance No. 50 of 2008. https://www.wipo.int/edocs/lexdocs/laws/en/bd/bd023en. pdf. Accessed 24 Feb. 2020.

62. The Gazette of India. The right to information act, 2005:No. 22 of 2005. https://rti.gov.in/rti-act.pdf. Accessed 24 Feb. 2020.

63. Right to Information Act, 2064, 2007.http://www.lawcommission.gov.np/en/ wp-content/uploads/2018/10/right-to-information-act-2064-2007.pdf accessed 24 Feb. 2020.

64. Gazette of the Democratic Socialist Republic of Sri Lanka. Right to information Act, no. 12 of 2016.https://www.media.gov.lk/images/pdf_ word/2016/12-2016_E.pdf. Accessed 24 Feb. 2020.

65. Bangladesh Gazette. Public-interest Information Disclosure Act (Provide Protection) https://mrdibd.org/downloads/Whistleblower_protection_act_2 011_English.pdf. Accessed 24 Feb. 2020

66. The India Gazette. THE WHISTLE BLOWERS PROTECTION ACT, 2011NO. 17 OF 2014. https://www.prsindia.org/uploads/media/Public\%20Disclosure/ Whistle\%20Blowers\%20Protection\%20Act,\%202011.pdf. Accessed 24 Feb. 2020.

67. The Gazette of India. The lokpal and lokayuktas act, 2013 (NO. 1 OF 2014). https://dopt.gov.in/sites/default/files/407_06_2013-AVD-IV-09012014_0.pdf. Accessed 24 Feb. 2020

68. The Gazette of India. The prevention of corruption (amendment) act, 2018 NO. 16 OF 2018. http://www.egazette.nic.in/writereaddata/2018/187644. pdfAccessed 24 Feb. 2020

69. United Nations Office on Drugs and Crime. World Drug Report 2004. United Nations Publications; 2004. https://www.unodc.org/unodc/en/data-andanalysis/WDR-2004.html. Accessed 24 Feb. 2020.

70. Rose-Ackerman S. The challenge of poor governance and corruption. 2004. Available from: https://www.copenhagenconsensus.com/sites/default/files/ PP+-+Corruption1+FINISHED.pdf. Accessed 16 July 2019.

71. Bruckner T. The ignored pandemic: how corruption in health care service delivery threatens Universal Health Coverage. Berlin: Transparency International (TI); 2019. http://ti-health.org/wp-content/uploads/2019/03/ IgnoredPandemic-WEB-V2.pdf. Accessed 24 Feb 2020.

72. Hutchinson E, Balabanova D, McKee M. We need to talk about corruption in health systems. Int J Health Pol Manag. 2019;8(4):191.
73. Gaitonde R, Oxman AD, Okebukola PO, Rada G. Interventions to reduce corruption in the health sector. Cochrane Database Syst Rev 2016(8). https://doi.org/10.1002/14651858.cd008856.pub2.

74. Maduke T. Corruption in health sectors of low- and middle- income countries: a report on preliminary findings from a survey of health sector leaders and managers in 95 countries: Leadership, Management \& Governance (LMG) Project, USAID. WAshington DC: USAID; 2013.

75. Evans T. Solidarity and security in global heath what can we learn from the Ebola crisis? Keynote speech at PMAC opening plenary. 2015. https://www. worldbank.org/en/news/speech/2015/01/29/solidarity-security-in-globalhealth-what-can-we-learn-from-ebola-crisis. Accessed 15 July 2019.

76. Lipsky M. Street-level bureaucracy: dilemmas of the individual in public services. New York: Russel Sage Foundation; 2010.

77. Hossain N. Rude accountability: informal pressures on frontline bureaucrats in Bangladesh. Dev Change. 2010;41(5):907-28.

78. Berlan D, Shiffman J. Holding health providers in developing countries accountable to consumers: a synthesis of relevant scholarship. Health Pol Plan. 2011;27(4):271-80.

79. Gurung G, Derrett S, Gauld R, Hill PC. Why service users do not complain or have 'voice': a mixed-methods study from Nepal's rural primary health care system. BMC Health Servi Res. 2017;17(1):81.

80. Sudarshan H, Prashanth NS. Good governance in health care: the Karnataka experience. Lancet. 2011;377(9768):790-2.

81. Afrin S, Barpanda S, Das A. Women in the lead: Monitoring Health service. New Delhi: Naripokkho, Open Society Foundation, Centre for Health \& Social Justice (CHSJ); 2013.

82. Alam W, Karim R, Islam S. ACC's public hearing as a means of controlling corruption: effectiveness, challenges and way forward. Dhaka: Transparency International Bangladesh; 2017.

83. Šumah Š (February 21st 2018). Corruption, Causes and Consequences, Trade and Global Market, Vito Bobek, IntechOpen, DOl: https://doi.org/10.5772/ intechopen.72953. Available from: https://www.intechopen.com/books/ trade-and-global-market/corruption-causes-and-consequences.

84. Garcia P. Corruption in global health: the open secret. Lancet. 2019;394: 2119-24.

85. Kelsall T, Hart T, Laws E. Political settlements and pathways to universal health coverage, vol. 432. London: ODI Working Paper; 2016.

\section{Publisher's Note}

Springer Nature remains neutral with regard to jurisdictional claims in published maps and institutional affiliations.

Ready to submit your research? Choose BMC and benefit from:

- fast, convenient online submission

- thorough peer review by experienced researchers in your field

- rapid publication on acceptance

- support for research data, including large and complex data types

- gold Open Access which fosters wider collaboration and increased citations

- maximum visibility for your research: over $100 \mathrm{M}$ website views per year

At $\mathrm{BMC}$, research is always in progress.

Learn more biomedcentral.com/submissions 